\title{
Correction to: does multidisciplinary rehabilitation of tortured refugees represent 'value-for-money'? A follow-up of a Danish case-study
}

Line Bager ${ }^{1}$, Kristian Schultz Hansen ${ }^{2}$, Carit Jacques Andersen ${ }^{3}$ and Shr-Jie Wang ${ }^{1 *}$

\section{Correction}

Following publication of the original article [1], the authors reported a correction in the name of one of the authors.

The name in the original article is:

Shr-Jie Sharlenna Wang.

The correct name is:

Shr-Jie Wang.

\section{Author details}

'Danish Institute Against Torture, Bryggervangen 55, 2100 Copenhagen, Denmark. ${ }^{2}$ Department of Health Services Research, Institute of Public Health, University of Copenhagen, Oester Farimagsgade 5, 1014 Copenhagen, Denmark. ${ }^{3}$ Decisionconsult A/S, Herluf Trolles Vej 243, 5220 Odense, Denmark.

Received: 1 June 2018 Accepted: 4 June 2018

Published online: 13 June 2018

\section{Reference}

1. Bager $\mathrm{L}$, et al. Does multidisciplinary rehabilitation of tortured refugees represent 'value-for-money'? A follow-up of a Danish case-study. BMC Health Serv Res. 2018;18:365. https://doi.org/10.1186/s12913-018-3145-3.

\footnotetext{
* Correspondence: sjw@dignityinstitute.dk

${ }^{1}$ Danish Institute Against Torture, Bryggervangen 55, 2100 Copenhagen, Denmark

Full list of author information is available at the end of the article
} 